\title{
1. CALCAREOUS NANNOFOSSIL BIOSTRATIGRAPHY OF THE NANKAI TROUGH ${ }^{1}$
}

\author{
Gunnar Olafsson 2,3
}

\begin{abstract}
ODP Leg 131 recovered nannofossil-bearing sediments from Site 808 in the Nankai Trough, western Pacific Ocean. Three holes were examined for nannofossils, $808 \mathrm{~A}, 808 \mathrm{~B}$, and $808 \mathrm{C}$. A total of 22 nannofossil events were recognized, of which 10 are used as zonal markers.

The sediments recovered from Hole $808 \mathrm{~A}(0-111.4 \mathrm{mbsf})$ contain Pleistocene nannofossil assemblages that are mostly well preserved. All samples from this hole were assigned to nannofossil Zone NN21.

The nannofossil assemblages observed in Hole 808B (111.0-358.8 mbsf) are poorly to well preserved and were all assigned to the Pleistocene. The NN21/NN20 Boundary is placed at $230.7 \pm 4.4 \mathrm{mbsf}$.

Hole $808 \mathrm{C}$ was cored from 298.5 to $1327 \mathrm{mbsf}$ and basalt was reached at $1289.9 \mathrm{mbsf}$. The sediments recovered range in age from the upper part of Zone NN20 of the Pleistocene to Zone NN5 of the middle Miocene and contain poorly to well-preserved nannofossil assemblages. The Pliocene/Pleistocene Boundary, marked by the FO Gephyrocapsa caribbeanica, was placed at $776.3 \pm 1.6 \mathrm{mbsf}$, and the Miocene/Pliocene Boundary is tentatively placed at $955.9 \pm 1.5 \mathrm{mbsf}$.

The lowermost sediments above basement as well as a sediment sample intercalated between basalt flows are assigned to Zone NN5, with an age of approximately $15 \mathrm{Ma}$.

Age estimates provided by nannofossils show that the sedimentation rate in the trench-fill deposits of the Nankai Trough was very high, $800-1350 \mathrm{~m} / \mathrm{m} . \mathrm{y}(0-0.46 \mathrm{Ma})$, whereas in the Shikoku Basin deposits $(>0.46 \mathrm{Ma})$, the sedimentation rate was much lower $(24-200 \mathrm{~m} / \mathrm{m}, \mathrm{y})$. These age estimates also provide an extrapolated age of approximately $15 \mathrm{Ma}$ for the basaltic basement at Site 808 .
\end{abstract}

\section{INTRODUCTION}

The Nankai Trough area is a topographic manifestation of the subduction boundary between the Shikoku Basin, which is a part of the Philippine Sea Plate, and the Honshu Arc in the western Pacific Ocean (Seno, 1977). Leg 131 of the Ocean Drilling Program (ODP) was the third drilling cruise to the Nankai Trough. On two previous DSDP legs in the Nankai Trough region, three sites in the trough and on the slope were drilled, all of which are west of Site 808 (Fig. 1).

During DSDP Leg $31,611 \mathrm{~m}$ of sediments were penetrated in the toe of the accretionary prism at Site 298. The oldest sediments recovered at this site are of early Pleistocene age. At Site 297 the hemipelagic sequence of the Shikoku Basin ocean floor was drilled; the oldest sediments recovered are of middle Miocene age, Sphenolithus heteromorphus Zone NN5 (Ingle, Karig, et al., 1975; Ellis, 1975).

Site 582 of DSDP Leg 87 penetrated $750 \mathrm{~m}$ of the undeformed trench fill, a 550-m-thick turbidite sequence overlying Pleistocene-toPliocene hemipelagic sediments (Discoaster brouweri Zone NN18). Site 583 was drilled at the toe of the accretionary prism (Kagami, Karig, Coulburn, et al., 1986). The oldest sediments at Site 583 are early Pleistocene (Gephyrocapsa oceanica Zone NN20; Lang, 1986).

Leg 131 was a continuation of studies begun during Leg 87 (Kagami, Karig, Coulburn, et al., 1986), but with much stronger emphasis on physical properties, logging, and downhole experiments. Seven holes were drilled at Site 808 in the toe of the Nankai accretionary prism (Fig. 1). Cores from Holes $808 \mathrm{~A}, 808 \mathrm{~B}$, and $808 \mathrm{C}$ were examined for calcareous nannofossils, providing a time frame necessary for understanding the history of the evolution of the Nankai Trough.

\footnotetext{
${ }^{1}$ Hill, I.A., Taira, A., Firth, J.V., et al., 1993. Proc. ODP, Sci. Results, 131: College Station, TX (Ocean Drilling Program).

${ }^{2}$ Department of Geology and Geochemistry, Stockholm University, S-10691 Stockholm, Sweden.

${ }^{3}$ Present address: Marine Research Institute, P.O. Box 390, Skúlagata 4, 121 Reykjavik, Iceland.
}

\section{METHODS}

Smear slides were prepared for each sample using either Ayal or Norland Optical Adhesive as a mounting medium. The calcareous nannofossils were examined in the smear slides by standard lightmicroscopy techniques (plane-polarized light, phase contrast, or cross-polarized light at approximately $\times 790$, or $\times 1250$ ).

Calcareous nannofossils often show signs of both strong etching and strong overgrowth; more dissolution-resistant forms add secondary calcite provided by more dissolution-prone morphotypes. In constructing the range charts (Tables 1, 2, and 3) the following simple codes were used to depict the preservation state of the nannofossil assemblages:

$\mathrm{G}=$ Good. Little or no evidence of dissolution and/or secondary overgrowth of calcite, diagnostic characteristics fully preserved.

$\mathrm{M}=$ Moderate. Dissolution and/or secondary overgrowth partially alter primary morphological characteristics, but nearly all specimens can be identified at the species level.

$\mathrm{P}=$ Poor. Severe dissolution, fragmentation, and/or secondary overgrowth with primary features largely destroyed; many specimens cannot be identified at the species and/or generic level.

Abundance estimates of the nannofossils in the smear slides were made on optimum density areas of the slide, that is, areas where most of the field was covered with sample material without appreciable piling of specimens or sample material. Four different levels of relative abundances, similar to the format outlined by Hay (1970) were defined as follows:

$\mathrm{A}=$ Abundant: $10 \%-50 \%$ (usually more than 10 specimens per viewfield).

$\mathrm{C}=$ Common: $1 \%-10 \%$ (1 to 10 specimens per viewfield $)$.

$\mathrm{F}=\mathrm{Few}: 0.1 \%-1 \%$ (1 specimen per 1 to 10 viewfields).

$\mathrm{R}=$ Rare: $<0.1 \%$ (only 1 specimen in more than 10 viewfields).

The abundances of selected species are shown in Tables 1,2, and 3, which were constructed using the method outlined by Wei (1990). 


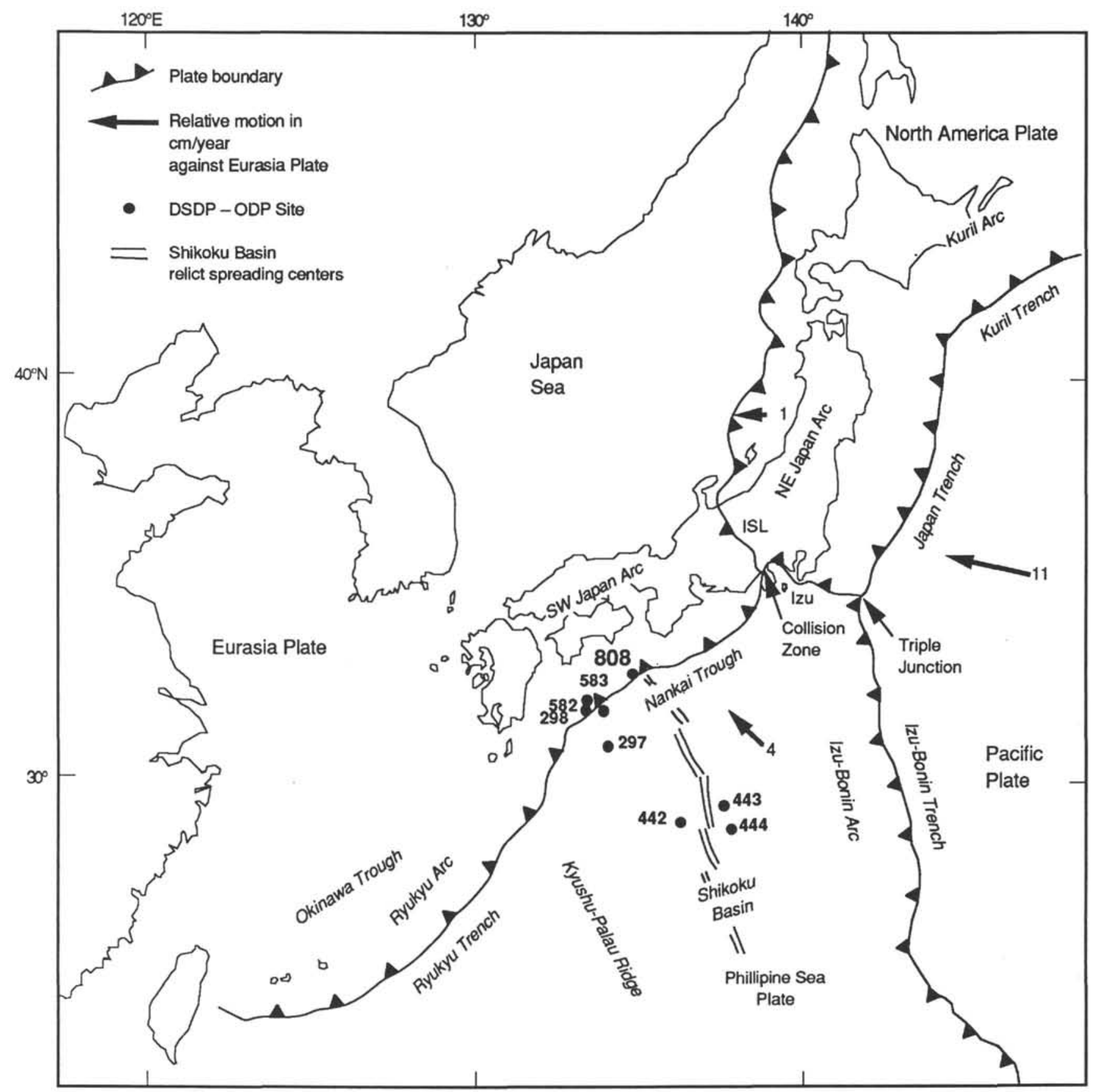

Figure 1. Location map showing the sites drilled in the Nankai Trough in Legs 31 (Sites 297 and 298), 87 (Sites 582 and 583) and 131 (Site 808 ) (from Taira, Hill, Firth, et al., 1991).

The relative abundance of Emiliania huxleyi out of 300 specimens per sample was counted in selected samples which made it possible to determine the first occurrence (FO) and the onset of the acme (OA) of E. huxleyi (Fig. 2).

Pseudoemiliania lacunosa was counted by the same method as for E. huxleyi, making it possible to determine the last occurrence (LO) of this species (Fig. 3).

Age estimates were primarily made on core-catcher samples. Additional samples from within the cores were examined to refine the age determinations in specific intervals.
Age estimates of Cenozoic calcareous nannofossil events have largely been derived by correlations to the geomagnetic polarity time scale (GPTS) of Berggren et al. (1985). In this study, more recent improved correlations between nannofossils and GPTS were also used (see Table 4 for references).

The standard Cenozoic nannofossil zonation scheme of Martini (1971) was used for the Leg 131 sediments. Additional biostratigraphic events, not used in Martini's zonal boundary definitions, were used, providing substantially improved biostratigraphic and biochronologic resolution (Table 4). 


\section{BIOSTRATIGRAPHIC SUMMARY}

\section{Hole 808A}

Hole 808A was APC-cored to 111.4 mbsf (meters below seafloor). The sediments recovered contain nannofossil assemblages that are mostly well preserved, and few samples are depleted of nannofossils. The estimated abundances of nannofossil specimens in the samples observed range from barren to abundant. In addition to the corecatcher samples, some additional samples were examined from undisturbed or little-disturbed muds within the cores. This was done because of the risk of sand caving in, reaching the core catcher, and giving a seemingly younger age for the assemblages observed.

All samples from Hole 808A were assigned to Zone NN21 of the Pleistocene (Table 5). The major components of the assemblages are gephyrocapsids (Gephyrocapsa oceanica, G. caribbeanica, G. parallela) and Emiliania huxleyi. Below Sample 131-808A-9H-5,5-6 cm, $80.88 \mathrm{mbsf}, E$. huxleyi is rare and occurs sporadically (Fig. 2).

The relative abundance of E. huxleyi out of 300 specimens per sample was counted in selected samples, which made it possible to determine the onset of the E. huxleyi acme $(0.09 \mathrm{Ma})$ between Samples 131-808A-9H-5, 5-6 cm, and -10H-CC (80.88 6.82 mbsf). Helicosphaera carteri, Coccolithus pelagicus, and Calcidiscus leptoporus are rare to few in Hole 808A. Other Pleistocene species rarely observed are Ceratolithus cristatus, Ceratolithus telesmus, Umbilicosphaera mirabilis, Umbilicosphaera sibogae, Pontosphaera japonica, and Rhabdosphaera species. Traces of reworked Miocene-Pliocene nannofossils were observed in most samples from Hole 808A, e.g., discoasters, sphenoliths, and reticulofenestrids.

\section{Hole 808B}

Hole $808 \mathrm{~B}$ was washed down to $111.0 \mathrm{mbsf}$ and $\mathrm{XCB}$-cored from 111.0 to 358.8 mbsf. The nannofossil assemblages observed are mostly well preserved. The upper part of Hole $808 \mathrm{~B}$ was assigned to Zone NN21 (Table 5) of the Pleistocene with the same nannofossil species as in Hole 808A, except that E. huxleyi is rare. The NN20/21 boundary $(0.28 \mathrm{Ma})$ was determined by the FO of $E$. huxleyi, observed between Samples 131-808B-13X-1, 42-43 cm, and -13X-CC, at $230.66 \pm 4.44 \mathrm{mbsf}$ (Fig. 2). Traces of reworked older species, the same as in Hole 808A, were observed throughout Hole 808B. Other Pleistocene species observed in Hole $808 \mathrm{~B}$ are Rhabdosphaera clavigera, Helicosphaera hyalina, Gephyrocapsa aperta, and Gephyrocapsa sinuosa.

\section{Hole 808C}

Hole $808 \mathrm{C}$ was washed to $298.5 \mathrm{mbsf}$ and RCB-cored from 298.5 to $1327 \mathrm{mbsf}$. The sediments recovered range in age from the upper part of Zone NN20 of the Pleistocene to Zone NN5 of the middle Miocene (Table 5).

\section{Pleistocene}

Pleistocene sediments recovered from Hole $808 \mathrm{C}$ contain moderately- to well-preserved nannofossil assemblages. Pseudoemiliania lacunosa was counted as a percentage of 300 specimens (Fig. 3). According to Thierstein et al. (1977), P. lacunosa commonly exhibits a steep decline in abundance followed by a small increase in abundance before the last occurrence. In Hole $808 \mathrm{C}$, the last occurrence is difficult to determine, both because of the sporadic occurrence and the low abundance of $P$. lacunosa toward the end of its range. Furthermore, the final part of the range of $P$. lacunosa occurs within the trench-to-basin transitional deposits, thus reworking could move the apparent extinction to a higher stratigraphic level. Thus, the last occurrence of $P$. lacunosa $(0.46 \mathrm{Ma})$ is tentatively placed between Samples 131-808C-34R-4, 134-135 cm, and -34R-CC (624.27 \pm 1.93

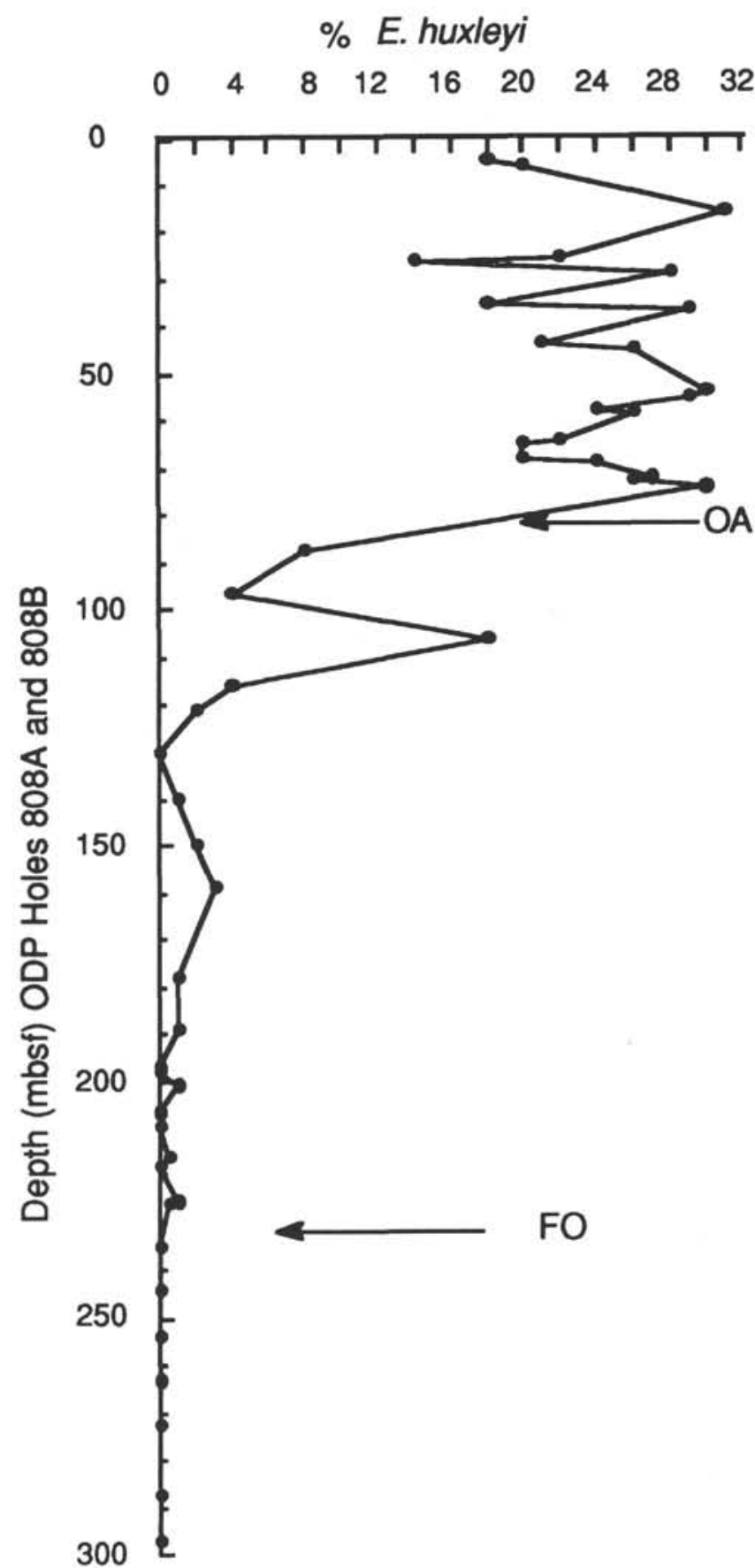

Figure 2. Abundance plot for Emiliania huxleyi at Site 808. Percent abundance of $E$. huxleyi out of 300 specimens counted.

mbsf), where it is preceded by a sharp decline in abundance at approximately $634 \mathrm{mbsf}$.

The LO of Reticulofenestra asanoi $(0.83 \mathrm{Ma})$ between Samples 131-808C-37R-CC, and -38R-CC, together with the last and first occurrences of large Gephyrocapsa $(>5.5 \mu \mathrm{m})$ between Samples 131-808C-41R-CC, and -42R-CC (1.10 Ma) and between Samples 131-808C-46R-CC, and -47R-CC (1.36 Ma), respectively, provided further datum levels that could be used for subdividing the Pleistocene (Sato, et al., 1991).

I chose to mark the Pliocene/Pleistocene Boundary (1.66 Ma, Sato, et al., 1991; Rio, et al., 1984) by the first consistent occurrence of Gephyrocapsa caribbeanica, which is placed between Samples 131- 


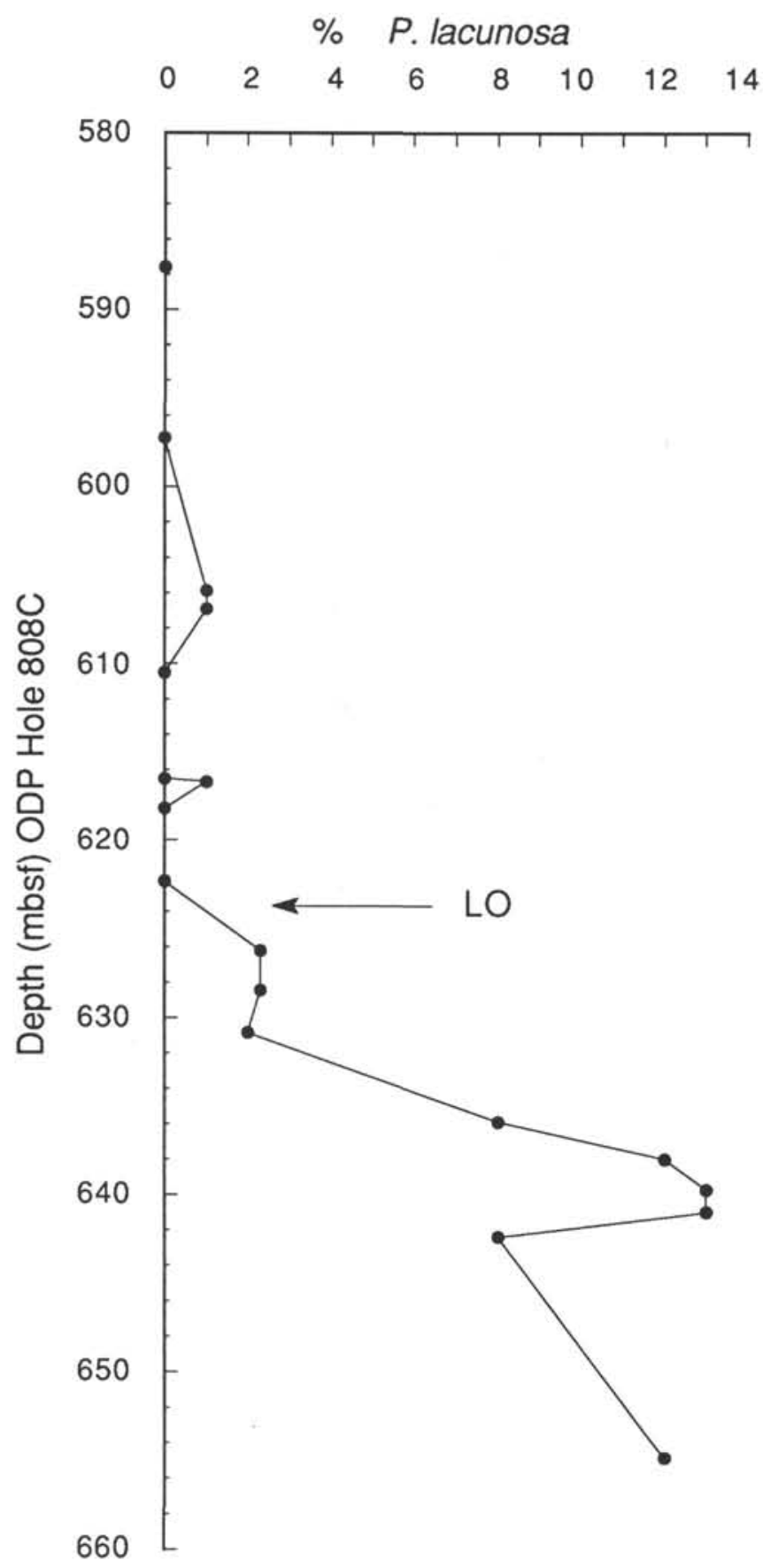

Figure 3. Abundance plot for Pseudoemiliania lacunosa at Site 808. Percent abundance out of 300 specimens counted. The last occurrence (extinction) is placed where the sharp decline in abundance is observed. The sporadic and low abundance occurrences above the $\mathrm{LO}$ are probably reworked specimens as they are found together with discoasters.

808C-50R-4, 59-60 cm, and -50R-6, 72-73 cm, at $776.26 \pm 1.56$ mbsf. Other Pleistocene species observed are Helicosphaera carteri, P. lacunosa, and Pontosphaera japonica.

\section{Pliocene}

The sediments recovered from the Pliocene in Hole $808 \mathrm{C}$ contain poorly to moderately well-preserved nannofossil assemblages. The LO of Discoaster brouweri (1.89 Ma) between Samples 131-808C$51 \mathrm{R}-3,85-86 \mathrm{~cm}$, and $-51 \mathrm{R}-5,77-78 \mathrm{~cm}(785.42 \pm 1.46 \mathrm{mbsf})$ marks the top of Zone NN18 of the Pliocene. Sample 131-808C-52R-5, $25-26 \mathrm{~cm}$, contains D. brouweri, and Sample 131-808C-52R-CC is barren of nannofossils. The nannofossil assemblage in Sample 131808C-53R-CC contained D. brouweri, D. pentaradiatus, and D. surculus, and was thus assigned to Zones NN16-17.

The LO of D. tamalis occurs within the upper part of Zone NN16 (2.65 Ma), between Samples 131-808C-56R-1, 80-81 cm, and -56R-3, $136-137 \mathrm{~cm}(830.98 \pm 1.78 \mathrm{mbsf})$.

The LO of Sphenolithus spp., occurs within the lower part of Zone NN16 (3.45 Ma), between Samples 131-808C-60R-3, 123-124 cm, and $-60 \mathrm{R}-5,51-52 \mathrm{~cm}(872.18 \pm 1.14 \mathrm{mbsf})$. The top of Zone NN15 (3.56 Ma) as marked by the LO of Reticulofenestra pseudoumbilica was placed between Samples 131-808C-60R-5, 51-52 cm, and -60R-CC (874.91 $\pm 1.59 \mathrm{mbsf})$. Amaumolithus tricorniculatus was not observed in Hole $808 \mathrm{C}$, therefore the NN14/NN15 Boundary (3.7 Ma) could not be determined. The FO D. asymmetricus $(4.1 \mathrm{Ma}$ ) was used to mark the NN13/NN14 Boundary between Samples 131-808C-62R-CC, and $-63 \mathrm{R}-1,41-42 \mathrm{~cm}$, at $895.06 \pm 1.16 \mathrm{mbsf}$. Ceratolithus rugosus was rarely observed in Samples 131-808C-62R-CC, and -64R-CC, hence the bottom of Zone NN13, based on the FO of C. rugosus (4.6 Ma), is tentatively set between Samples 131-808C-64R-CC, and -65R-1, $35-36 \mathrm{~cm}$, at $913.92 \pm 6.21$ mbsf. The total absence of Ceratolithus acutus and the sporadically and rarely observed Triquetrorhabdulus rugosus cause the Miocene/Pliocene Boundary (4.9 Ma, Zijderveld et al., 1986 ) to be difficult to determine. The LO of T. rugosus (4.9 Ma), which also coincides with the LO of Discoaster quinqueramus (5.0 Ma), occurs between Samples 131-808C-69R-1, 62-63 cm, and -69R-3, 61-62 cm ( $955.92 \pm 1.50 \mathrm{mbsf}$ ), and the Miocene/Pliocene Boundary is therefore tentatively placed at this level.

\section{Miocene}

The preservation observed in the upper Miocene assemblages is poorer than in the sediments above and below, and the abundance diminishes down toward the basalt. Zone NN11 is defined by the range of $D$. quinqueramus. The LO of $D$. quinqueramus (5.0 Ma) between Samples 131-808C-69R-1, 62-63 cm, and -69R-3, 61-62 cm (955.92 \pm $1.50 \mathrm{mbsf}$ ) marks the top of Zone NN11, whereas the FO of $D$. quinqueramus (7.5 Ma) between Samples 131-808C-73R-5, 63-65 $\mathrm{cm}$, and -77R-CC (1018.92 $\pm 20.18 \mathrm{mbsf})$ marks the base of Zone NN11. Discoaster hamatus was not observed in Hole $808 \mathrm{C}$, therefore neither the NN10/NN9 nor the NN9/NN8 boundaries could be determined. Because of the sporadic occurrence and low abundance of Catinaster coalitus, its first occurrence, which marks the bottom of NN8 $(11.1 \mathrm{Ma})$, could not be determined precisely. Thus, this zonal boundary was tentatively placed between Samples 131-808C-83R-CC, and $-84 \mathrm{R}-3,47-48 \mathrm{~cm}(1092.54 \pm 2.95 \mathrm{mbs})$. Because of the sporadic occurrence and low abundances of Discoaster kugleri, the NN6/NN7 Boundary (12.2 Ma) could not be determined precisely. Therefore, Zones NN6 and NN7 are combined in this study.

The LO of Cyclicargolithus floridanus (11.5 Ma) occurs within the lower part of Zone NN7, between Samples 131-808C-88R-CC, and $-89 \mathrm{R}-\mathrm{CC}$ (1141.45 $\pm 4.70 \mathrm{mbsf})$.

Quantitatively determined last occurrences of $C$. floridanus have been reported to occur slightly above the LO of Spenolithus heteromorphus in the equatorial Pacific Ocean (Olafsson, 1989) and at the same stratigraphic level as the LO of $S$. heteromorphus in the equatorial Indian Ocean (Fornaciari et al., 1990). The last occurrence of C. floridanus has also been quantitatively determined in sediments from DSDP Site 608 in the north Atlantic Ocean $\left(42^{\circ} \mathrm{N}\right)$. There the obtained age of this event was 11.5 Ma (Olafsson, unpubl. data). According to Bukry (1973) and Parker et al. (1985), the LO of $C$. floridanus is near the top of Zone NN6 (FO of D. kugleri) but it has also been recorded within Zone NN7 in other sections (Roth and Thierstein, 1972; Miller et al., 1985). These observations indicate that the last occurrence of $C$. floridanus could be latitudinally controlled, with a younger age in higher latitudes. 
Table 1. Pleistocene range chart for stratigraphically important nannofossil species. See text for explanation of abundances.

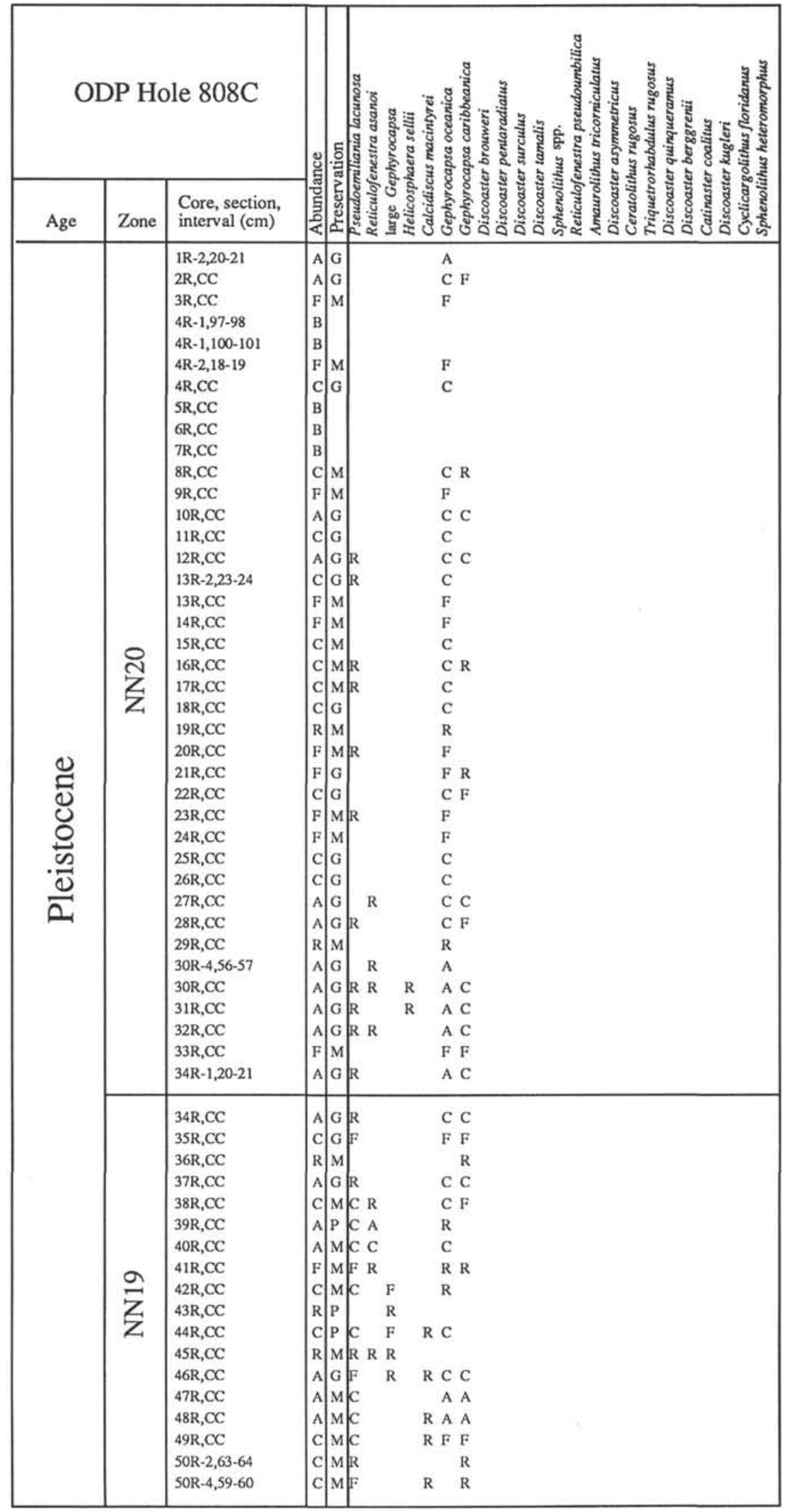


Table 2. Pliocene range chart for stratigraphically important nannofossil species.

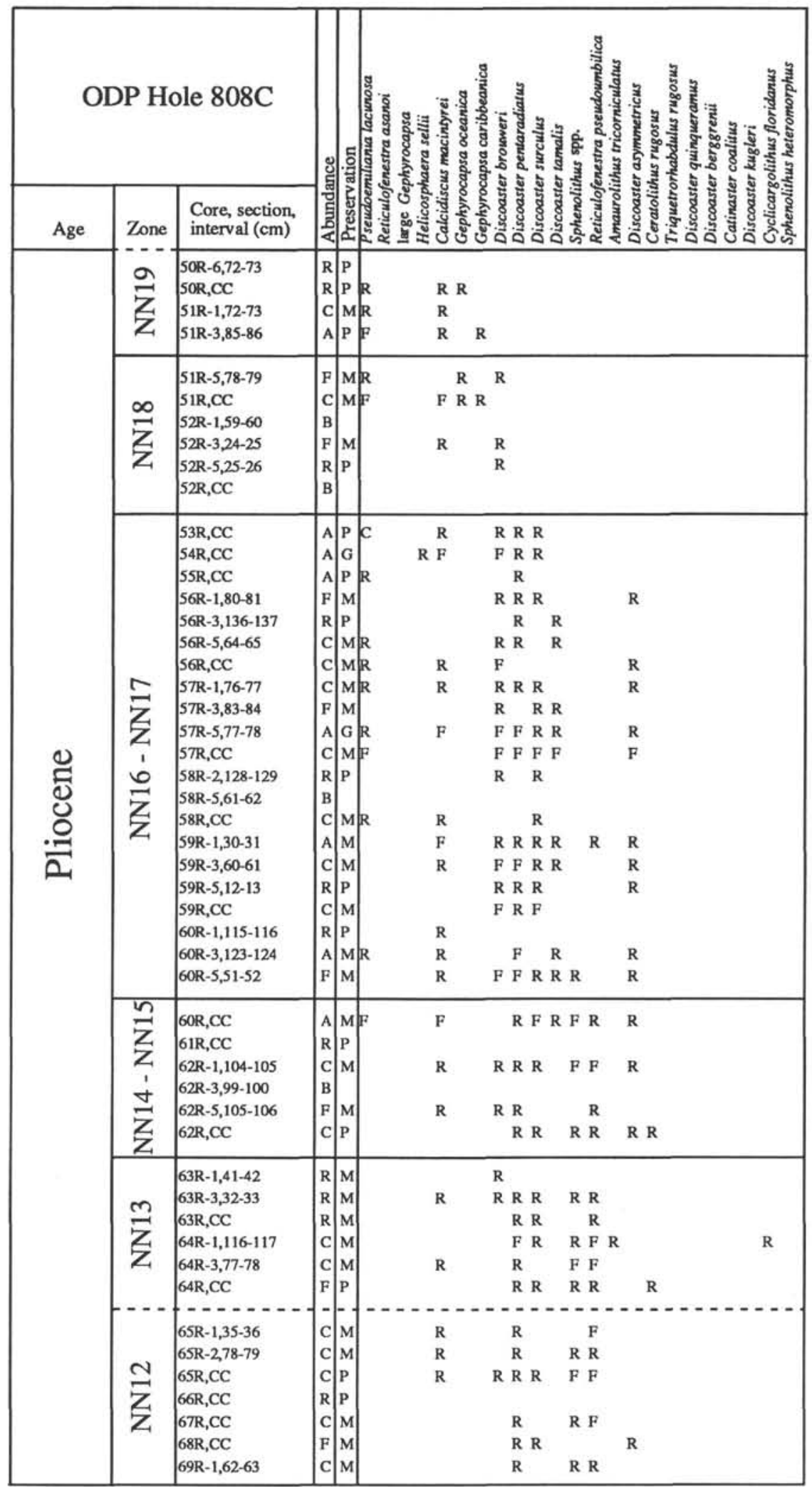


Table 3. Miocene range chart for stratigraphically important nannofossil species.

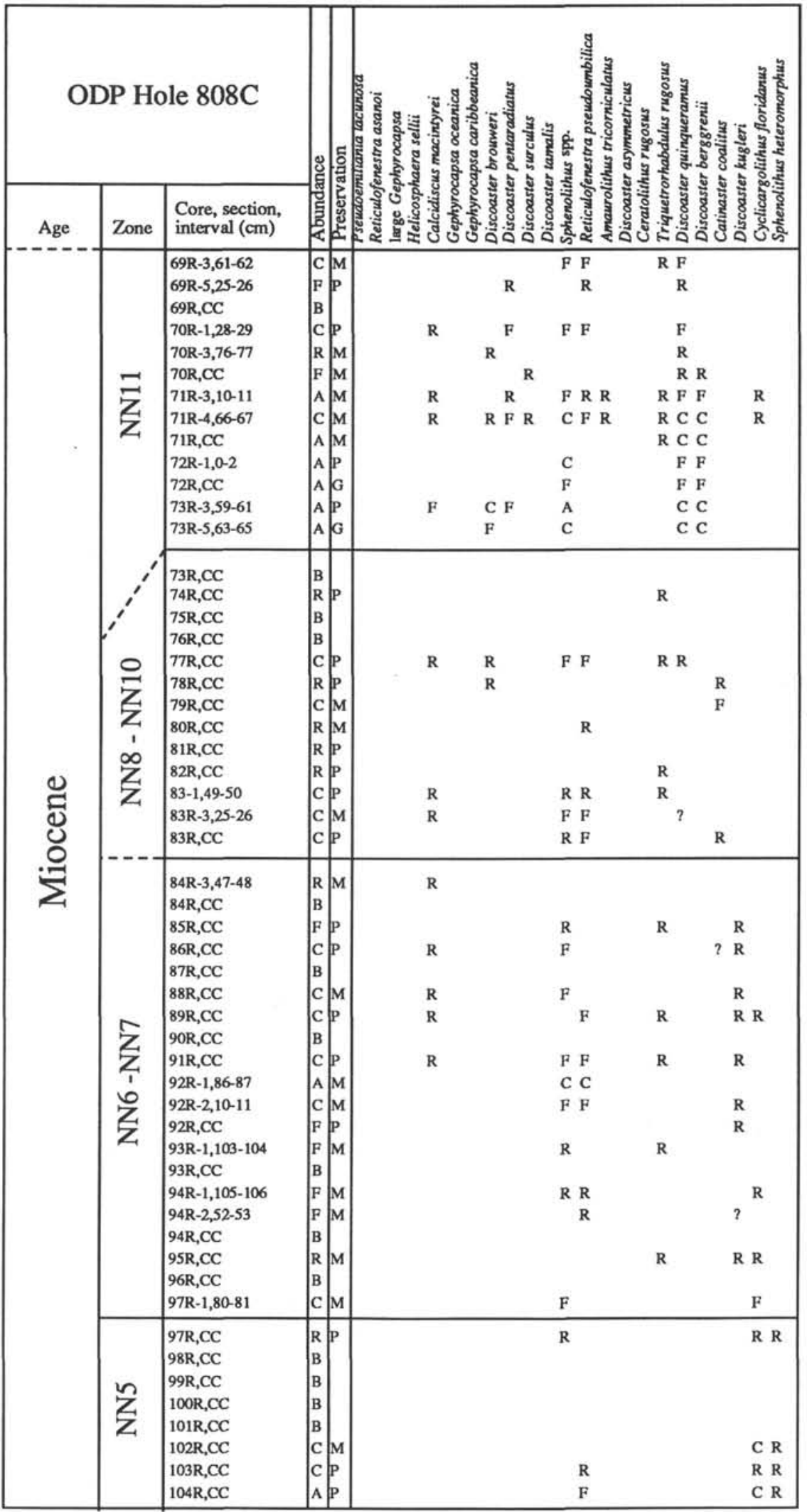


The lowermost zonal boundary that could be assessed in Hole $808 \mathrm{C}$ was the LO of Sphenolithus heteromorphus (13.5 Ma) between Samples 131-808C-97R-1, 80-81 cm, and -97R-CC (1219.25 \pm 4.45 mbsf). This event marks the top of Zone NN5 of the middle Miocene. The lowermost sample of the sedimentary sequence that was examined (131-808C-104R-CC) contains abundant moderately wellpreserved nannofossils. Helicosphaera ampliaperta, the last occurrence of which marks the top of Zone NN4, was not observed in that sample. One baked sediment sample from within the basalt (131808C-106R-2, piece 9) contains common moderately well-preserved nannofossils. Sphenolithus heteromorphus, C. floridanus, and Discoaster deflandrei, were the most common species observed. No $H$. ampliaperta was observed. This fact, and one poorly preserved specimen of $C$. macintyrei, place this sample within Zone NN5.

\section{AGE ESTIMATES AND SEDIMENTATION RATES}

The age depth/plot for ODP Site 808, based on the nannofossil events gathered in this study, is shown in Figure 4. The events and their age estimates are summarized in Table 4 together with the resulting sedimentation rates. Out of a total of 22 nannofossil events recognized in Site 808, 10 could be used as zonal markers, and 16 were selected to construct the age/depth plot, providing the time frame necessary for the understanding of the evolution of the Nankai Trough.

The most prominent feature of the age/depth plot is the high sedimentation rate, approximately $1000 \mathrm{~m} / \mathrm{m}$.y., observed within the trench-fill deposits (Pickering, et al., this volume) at Site 808.

In the lower part of the Shikoku Basin deposits (between events 20 and 22 in Fig. 4), the sedimentation rate is relatively high, probably because of high input of volcaniclastic deposits in the earliest stages of the evolution of the trough. With the onset of the hemipelagic sedimentation (approximately at event 20 in Fig. 4), the conditions became stable, which is reflected in a lower sedimentation rate (see Pickering et al. in this volume for further discussion on the evolution of the trough).

If the age estimates provided by the calcareous nannofossils are used, the age of the basement, given by extrapolation from events 20 and 22 (Table 4), is approximately $15 \mathrm{Ma}$.

\section{CONCLUSIONS}

The low diversity of the nannofossil assemblages described from previous DSDP legs from the Nankai Trough area (Ellis, 1975; Lang, 1986 ) is also revealed in samples from Leg 131. The preservation of nannofossils in Site 808 sediments (approx. $4700 \mathrm{~m}$ water depth; Taira, Hill, Firth, et al., 1991) is generally better than at Sites 298 (approx. $4000 \mathrm{~m}$ water depth; Ingle, Karig, et al., 1975) and 582 (approx. $4500 \mathrm{~m}$ water depth; Kagami, Karig, Coulburn, et al., 1986), and fewer samples are depleted of nannofossils.

The most significant feature of the Site 808 samples is that, despite the corrosiveness of water at depth, high input of terrigenous material, and the general low diversity of species within the samples, relatively few samples were completely barren of nannofossils. Out of 17 nannofossil zones (NN5 to NN21) that are defined within the time interval examined, 11 zones were recognized, making it possible to construct a useful nannofossil biostratigraphy for the Nankai Trough.

\section{ACKNOWLEDGMENTS}

I thank Dr. J. Backman for his support through the work with this project. I am grateful to Dr. Kjartan Thors, Dr. Domenico Rio, and Dr. Toshiaki Takayama for suggestions that improved this manuscript. I gratefully acknowledge the financial support given by the Nordic Minister Council, the Swedish Natural Science Research Council, and the Icelandic Science Council.

\section{REFERENCES}

Backman, J., Schneider, D.A., Rio, D., and Okada, H., 1990. Neogene low-latitude magnetostratigraphy from Site 710 and revised age estimates of Miocene nannofossil datum events. In Duncan, R.A., Backman, J., Peterson, L.C., et al., Proc. ODP, Sci. Results, 115: College Station, TX (Ocean Drilling Program), 271-276.

Backman, J. and Shackleton N.J., 1983. Quantitative biochronology of Pliocene and early Pleistocene calcareous nannofossils from the Atlantic, Indian and Pacific Oceans. Mar. Micropaleontol., 8:141-170.

Berggren, W.A., Kent, D.V., and van Couvering, J.A., 1985. The Neogene: Part 2. Neogene geochronology and chronostratigraphy. In Snelling, N.J. (Ed.), The Chronology of the Geological Record. Geol. Soc. London Mem., 10:211-260.

Bukry, D., 1973. Low-latitude coccolith biostratigraphic zonation. In Edgar, N.T., Saunders, J.B., et al., Init. Repts. DSDP, 15: Washington (U.S. Govt. Printing Office), 685-703.

Ellis, C.H., 1975. Calcareous nannofossil biostratigraphy - Leg 31, DSDP. In Karig, D.E., Ingle, J.C., et al., Init. Repts. DSDP, 31: Washington (U.S. Govt. Printing Office), 655-676.

Fornaciari, E., Raffi, I., Rio, D., Villa, G., Backman, J., and Olafsson, G., 1990. Quantitative distribution patterns of Oligocene and Miocene calcareous nannofossils from western equatorial Indian Ocean. In Duncan, R.A., Backman, J., Peterson, L.C., et al., Proc. ODP, Sci. Results, 115: College Station, TX (Ocean Drilling Program), 237-254.

Hay, W.W., 1970. Calcareous nannofossils from cores recovered on Leg 4. In Bader, R.G., Gerard, R.D., et al., Init. Repts. DSDP, 4: Washington (U.S. Govt. Printing Office), 455-501.

Ingle, J.C., Karig, D.E., et al., 1975. Init. Repts. DSDP, 31: Washington (U.S. Govt. Printing Office).

Kagami, H., Karig, D.E., Coulburn, W.C., et al., 1986. Init. Repts. DSDP, 87: Washington (U.S. Govt. Printing Office).

Lang, T.H., 1986. Calcareous nannofossils from the Nankai Trough and Japan Trench, Deep Sea Drilling Project Leg 87. In Kagami, H., Karig, D.E., Coulburn, W.C., et al., Init. Repts. DSDP, 87: Washington (U.S. Govt. Printing Office), 573-585.

Martini, E., 1971. Standard Tertiary and Quaternary calcareous nannoplankton zonation. In Farinacci, A. (Ed.), Proc. 2nd Planktonic Conf. Roma. Rome (Ed. Tecnosci.), 2:739-785.

Miller, K.G., Aubry, M.-P., Kahn, M.J., Melillo, A.J., Kent, D.V. and Berggren, W.A., 1985. Oligocene-Miocene biostratigraphy, magnetostratigraphy, and isotopic stratigraphy of western North Atlantic. Geology, 13:257-261.

Olafsson, G., 1989. Quantitative calcareous nannofossil biostratigraphy of upper Oligocene to middle Miocene sediment from ODP Hole 667A and middle Miocene sediment from DSDP Site 574. In Ruddiman, W., Sarnthein, M., et al., Proc. ODP, Sci. Results, 108: College Station, TX (Ocean Drilling Program), 9-22.

Parker, M.E., Clark, M. and Wise, S.W., Jr., 1985. Calcareous nannofossils of Deep Sea Drilling Project Sites 558 and 563, North Atlantic Ocean: biostratigraphy and the distribution of Oligocene braarudosphaerids. In Bougault, H., Cande, S.C., et al., Init. Repts. DSDP, 82: Washington (U.S. Govt. Printing Office), 559-589.

Rio, D., Backman, J., and Raffi, I., 1984. Calcareous Nannofossil Biochronology and the Pliocene/Pleistocene Boundary. Univ. of Parma. Preprint.

Roth, P.H. and Thierstein, H.R., 1972. Calcareous nannoplankton: Leg 14 of the Deep Sea Drilling Project. In Hayes, D.E., Pimm, A.C., et al., Init. Repts. DSDP, 14: Washington (U.S. Govt. Printing Office), 421-485.

Sato, T., Kameon, K., and Takayama, T., 1991. Coccolith biostratigraphy of the Arabian Sea. In Prell, W.L., Niitsuma, N., et al., Proc. ODP, Sci. Results, 117: College Station, TX (Ocean Drilling Program), 37-54.

Seno, T., 1977. The instantaneous rotation of the Philippine Sea plate relative to the Eurasian plate. Tectonophysics, 42:209-226.

Taira, A., Hill, I., Firth, J.V., et al., 1991. Proc. ODP Init. Repts., 131: College Station, TX (Ocean Drilling Program).

Thierstein, H.R., Geitznauer, K.R., Molfino, B., and Shackleton, N.J., 1977. Global synchroniety of late Quaternary coccolith datum levels: validation by oxygen isotopes. Geology, 5:400-404.

Wei, W., 1990. A new technique for constructing camera-ready range charts using a Macintosh computer. INA Newsl., 12:62-64.

Zijderveld, J.D.A., Zachariasse, J.W., Verhallen, J.J.M., and Hilgen, F.J., 1986. The age of the Miocene-Pliocene boundary. Newsl. Stratigr., 16:169-181.

Date of initial receipt: 1 October 1991

Date of acceptance: 9 March 1992

Ms 131SR-103 


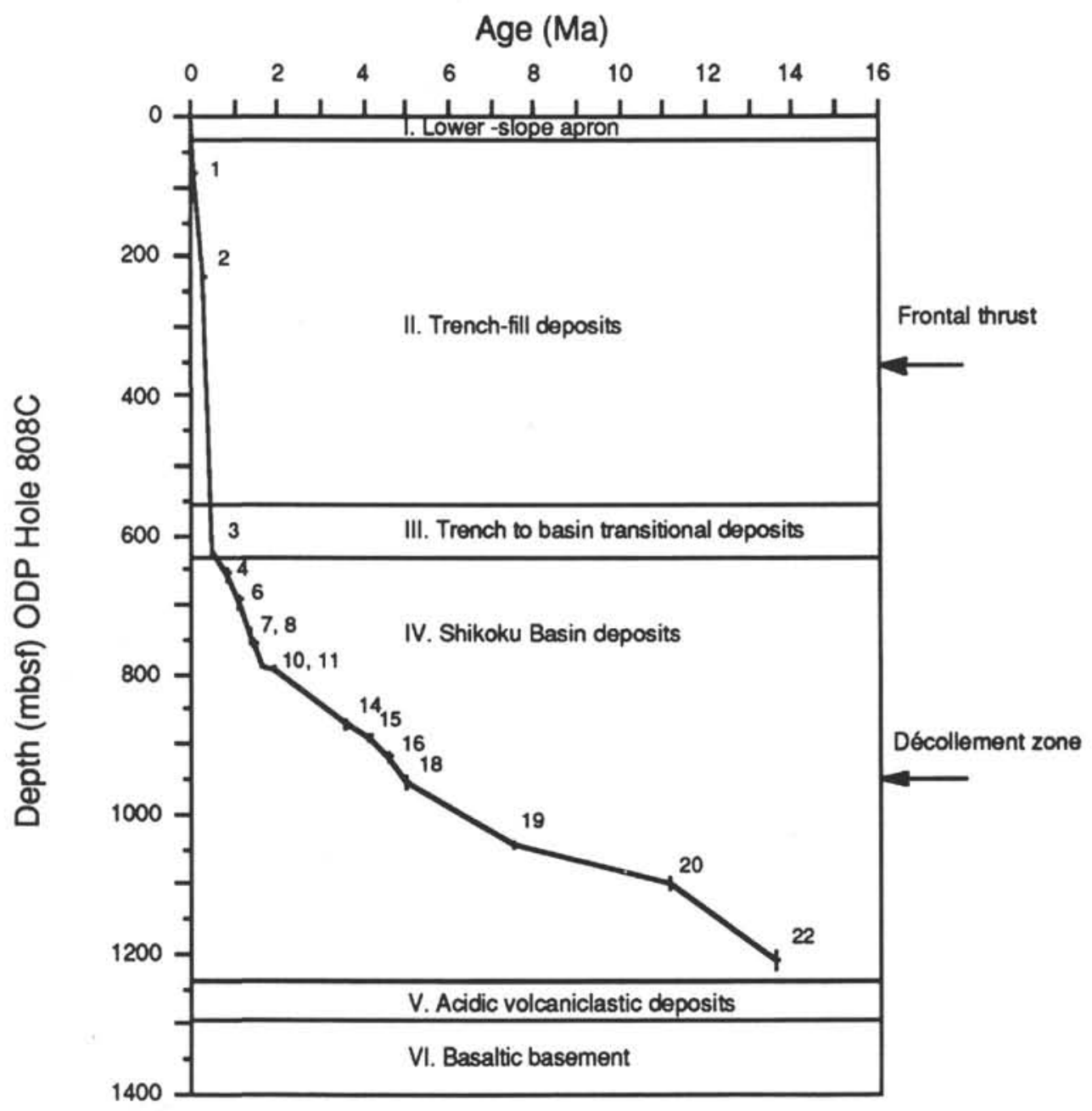

Figure 4. Age-depth plot for ODP Site 808 based on calcareous nannofossil events gathered in this study. The numbers refer to the number of the events shown in Table 4. The lithostratigraphy is from Taira, Hill, Firth, et al. (1991). 
Table 4. Summary of calcareous nannofossil events with age estimates and sedimentation rates. FO: first occurrence, LO: last occurrence, OA: onset of Acme.

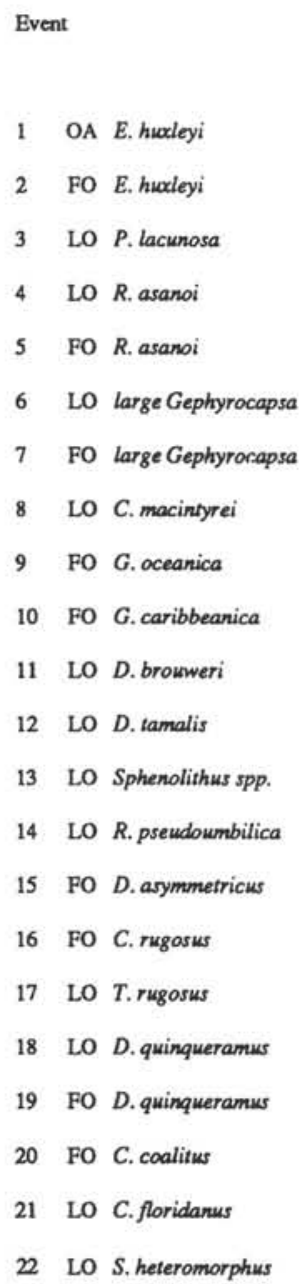

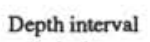

\begin{tabular}{ll} 
& $808 \mathrm{~A}-9 \mathrm{H}-5,5-6 \mathrm{~cm} / 10 \mathrm{H}, \mathrm{CC}$ \\
NN20 & $808 \mathrm{~B}-13 \mathrm{X}-1,42-43 \mathrm{~cm} / 13 \mathrm{X}, \mathrm{CC}$ \\
NN19 & $808 \mathrm{C}-34 \mathrm{R}-4,134-135 \mathrm{~cm} / 34 \mathrm{R}, \mathrm{CC}$ \\
& $808 \mathrm{C}-37 \mathrm{R}, \mathrm{CC} / 38 \mathrm{R}, \mathrm{CC}$ \\
& $808 \mathrm{C}-41 \mathrm{R}, \mathrm{CC} / 42 \mathrm{R}, \mathrm{CC}$ \\
& $808 \mathrm{C}-41 \mathrm{R}, \mathrm{CC} / 42 \mathrm{R}, \mathrm{CC}$ \\
& $808 \mathrm{C}-46 \mathrm{R}, \mathrm{CC} / 47 \mathrm{R}, \mathrm{CC}$ \\
& $808 \mathrm{C}-47 \mathrm{R}, \mathrm{CC} / 48 \mathrm{R}, \mathrm{CC}$ \\
& $808 \mathrm{C}-49 \mathrm{R}, \mathrm{CC} / 50-2,63-64 \mathrm{~cm}$ \\
& $808 \mathrm{C}-50 \mathrm{R}-4,59-60 \mathrm{~cm} / 50 \mathrm{R}-6,72-73 \mathrm{~cm}$ \\
NN18 & $808 \mathrm{C}-51 \mathrm{R}-3,85-86 \mathrm{~cm} / 51 \mathrm{R}-5,77-78 \mathrm{~cm}$ \\
& $808 \mathrm{C}-56 \mathrm{R}-1,80-81 \mathrm{~cm} / 56 \mathrm{R}-3,136-137 \mathrm{~cm}$ \\
& $808 \mathrm{C}-60 \mathrm{R}-3,123-124 \mathrm{~cm} / 60 \mathrm{R}-5,51-52 \mathrm{~cm}$ \\
\hline NN15 & $808 \mathrm{C}-60 \mathrm{R}-5,51-52 \mathrm{~cm} / 60 \mathrm{R}, \mathrm{CC}$ \\
\hline NN13 & $808 \mathrm{C}-62 \mathrm{R}, \mathrm{CC} / 63 \mathrm{R}-1,41-42 \mathrm{~cm}$ \\
\hline NN12 & $808 \mathrm{C}-64 \mathrm{R}, \mathrm{CC} / 65 \mathrm{R}-1,35-36 \mathrm{~cm}$ \\
& $808 \mathrm{C}-69 \mathrm{R}-1,62-63 \mathrm{~cm} / 69 \mathrm{R}-3,61-62 \mathrm{~cm}$ \\
\hline NN11 & $808 \mathrm{C}-69 \mathrm{R}-1,62-63 \mathrm{~cm} / 69 \mathrm{R}-3,61-62 \mathrm{~cm}$ \\
\hline NN10 & $808 \mathrm{C}-73 \mathrm{R}-5,63-65 \mathrm{~cm} / 7 \mathrm{R}, \mathrm{CC}$ \\
\hline NN7 & $808 \mathrm{C}-83 \mathrm{R}, \mathrm{CC} / 84 \mathrm{R}-3,47-48 \mathrm{~cm}$ \\
& $808 \mathrm{C}-88 \mathrm{R}, \mathrm{CC} / 89 \mathrm{R}, \mathrm{CC}$ \\
& $808 \mathrm{C}-97 \mathrm{R}-1,80-81 \mathrm{~cm} / 97 \mathrm{R}, \mathrm{CC}$ \\
&
\end{tabular}

$$
\text { (m) }
$$$$
\text { (mas) (m/m.y.) }
$$

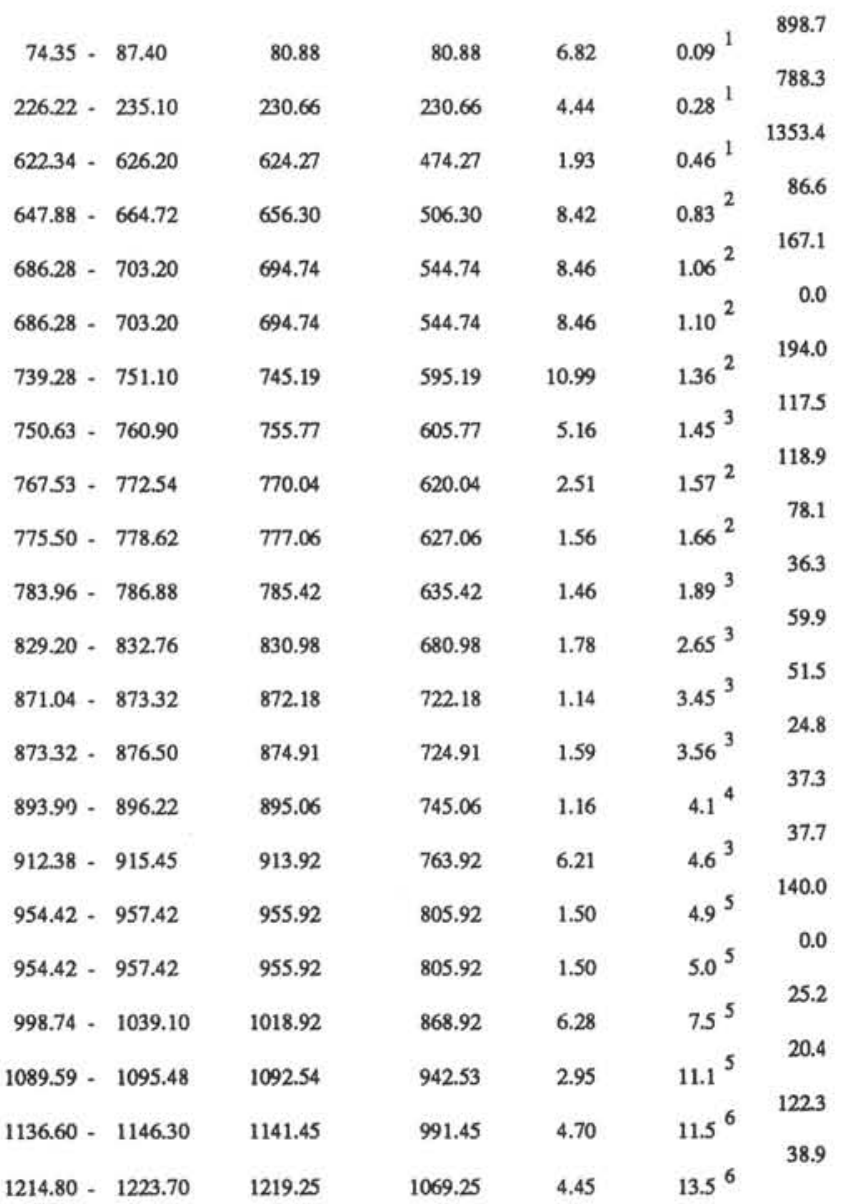


Table 5. Middle Miocene to Pleistocene zonal assignments for ODP Site 808.

\begin{tabular}{|c|c|c|c|c|}
\hline & $\begin{array}{l}\text { Martini (1971) } \\
\text { Zone }\end{array}$ & Hole $808 \mathrm{~A}$ & Hole 808B & Hole $808 \mathrm{C}$ \\
\hline 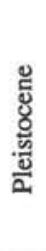 & $\begin{array}{l}\text { NN21 } \\
\text { NN20 } \\
\text { NN19 }\end{array}$ & $\begin{array}{l}1 \mathrm{H}-1,140-141 \\
13 \mathrm{H}, \mathrm{CC}\end{array}$ & $\begin{array}{l}2 \mathrm{X}-1,78-79 \\
13 \mathrm{X}-1,42-43 \\
13 \mathrm{X}, \mathrm{CC} \\
28 \mathrm{X}, \mathrm{CC}\end{array}$ & $\begin{array}{l}\text { 1R-2,20-21 } \\
34 \mathrm{R}-4,134-135 \\
\text { 34R,CC } \\
51 \mathrm{R}-3,85-86\end{array}$ \\
\hline 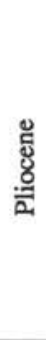 & $\begin{array}{l}\text { NN16-18 } \\
\text { NN14-NN15 } \\
\text { NN13 } \\
\text { NN12 }\end{array}$ & & & $\begin{array}{l}51 \mathrm{R}-5,77-78 \\
60 \mathrm{R}-5,51-52 \\
\\
60 \mathrm{R}, \mathrm{CC} \\
62 \mathrm{R}, \mathrm{CC} \\
\\
63 \mathrm{R}-1,41-42 \\
64 \mathrm{R}, \mathrm{CC} \\
65 \mathrm{R}, \mathrm{CC} \\
69 \mathrm{R}-1,62-65\end{array}$ \\
\hline 迩 & $\begin{array}{l}\text { NN11 } \\
\text { NN8-10 }\end{array}$ & & & $\begin{array}{l}\text { 69R-3,61-62 } \\
73 \mathrm{R}-5,63-65 \\
\\
74 \mathrm{R}, \mathrm{CC} \\
83 \mathrm{R}, \mathrm{CC} \\
\\
84 \mathrm{R}-3,47-48 \\
97 \mathrm{R}-1,80-81 \\
\text { 97R,CC } \\
\text { 106R-2, piece 9 }\end{array}$ \\
\hline
\end{tabular}

